\title{
Review \\ Emerging Treatment Options for Sarcopenia in Chronic Liver Disease
}

\author{
Yun Kim (iD)
}

Citation: Kim, Y. Emerging

Treatment Options for Sarcopenia in Chronic Liver Disease. Life 2021, 11 , 250. https://doi.org/10.3390/ life 11030250

Academic Editors: Dae Won Jun and Waqar K. Saeed

Received: 8 February 2021

Accepted: 15 March 2021

Published: 17 March 2021

Publisher's Note: MDPI stays neutral with regard to jurisdictional claims in published maps and institutional affiliations.

Copyright: (C) 2021 by the author. Licensee MDPI, Basel, Switzerland. This article is an open access article distributed under the terms and conditions of the Creative Commons Attribution (CC BY) license (https:// creativecommons.org/licenses/by/ $4.0 /)$.
Hanyang Medicine-Engineering-Bio Collaborative \& Comprehensive Center for Drug Development, Hanyang University, Seoul 04763, Korea; mn0701@hanyang.ac.kr; Tel.: +82-2-2290-9664 or +82-10-2013-9226

\begin{abstract}
Sarcopenia is characterized by a skeletal muscle disorder with progressive and generalized loss of muscle mass and function, and it increases the risk of adverse outcomes with considerable prevalence in patients with chronic liver disease. Sarcopenia in chronic liver disease underlies complicated and multifactorial mechanisms for pathogenesis, including alterations in protein turnover, hyperammonemia, energy disposal, hormonal changes, and chronic inflammation. The key contribution to sarcopenia in patients with chronic liver diseases can be the hyperammonemia-induced upregulation of myostatin, which causes muscle atrophy via the expression of atrophy-related genes. Several clinical studies on emerging treatment options for sarcopenia have been reported, but only a few have focused on patients with chronic liver diseases, with mostly nutritional and behavioral interventions being carried out. The inhibition of the myostatin-activin receptor signaling pathway and hormonal therapy might be the most promising therapeutic options in combination with an ammonia-lowering approach in sarcopenic patients with chronic liver diseases. This review focuses on current and emerging treatment options for sarcopenia in chronic liver diseases with underlying mechanisms to counteract this condition.
\end{abstract}

Keywords: sarcopenia; chronic liver disease; muscle protein turnover; cirrhosis; non-alcoholic fatty liver disease

\section{Introduction}

Sarcopenia is characterized by a skeletal muscle disorder with progressive and generalized loss of muscle mass, strength, and function, thus increasing the risk of adverse outcomes, such as physical disability and higher rates of hospitalization and mortality [1]. The term "sarcopenia" was first used in the 1980s to refer to age-related skeletal muscle decline [2]. The definition of sarcopenia has changed from muscle-wasting conditions with low muscle mass into a term involving muscle function in the current concept of sarcopenia $[3,4]$. The evolution of the definition is attributed to the fact that muscle function has been shown to be a more influential clinical biomarker than muscle mass alone $[5,6]$. The overall prevalence of sarcopenia was estimated at $10 \%$ in both men and women, which indicates that a considerable proportion of the elderly, even in a healthy population, has sarcopenia [7]. Moreover, sarcopenia is generally known to be associated with various chronic inflammatory states, including chronic liver disease [6]. It has been shown to be a significant risk factor for non-alcoholic fatty liver disease (NAFLD), regardless of obesity or metabolic syndrome [8-10]. This relationship was convincing because similar pathological factors, including insulin resistance and inflammation, exist between sarcopenia and NAFLD [11-13]. Notably, the prevalence rate of sarcopenia is assumed to be $30-70 \%$ in cirrhotic patients, with a higher rate among men than in women $(61.6 \% \mathrm{vs} .36 \%$, respectively) [14-16]. Minimal hepatic encephalopathy, a complication of liver cirrhosis, was significantly associated with the presence of either muscle mass loss or strength loss (60.9\% vs. $37.7 \%$, respectively) [17]. In addition, sarcopenia commonly develops in patients with end-stage liver disease, for which the prevalence of sarcopenia ranges from 14 to $78 \%$ and from 30 to $100 \%$ in patients before and after liver transplantation, respectively [18]. 
Furthermore, sarcopenia can be a clinically significant predictor of higher rates of mortality and infection [16,19], longer hospitalization [20], and increased economic burden [21], thus reducing the quality of life [22]. However, challenges arise because the mechanisms of sarcopenia in chronic liver diseases are poorly understood and no approved and effective therapeutics to counteract sarcopenia are available. Therefore, in this review, I focused on the current and emerging treatment options for sarcopenia in chronic liver diseases with underlying mechanisms to counteract this condition.

\section{Etiology of Sarcopenia in Chronic Liver Diseases}

Sarcopenia in chronic liver disease is a complicated and multifactorial disease with several main drivers, such as impairment in protein turnover, malnutrition, hyperammonemia, chronic inflammation, and hormonal changes (Figure 1). Understanding the hypotheses of sarcopenia development would play a key role in overcoming the therapeutic limitations.

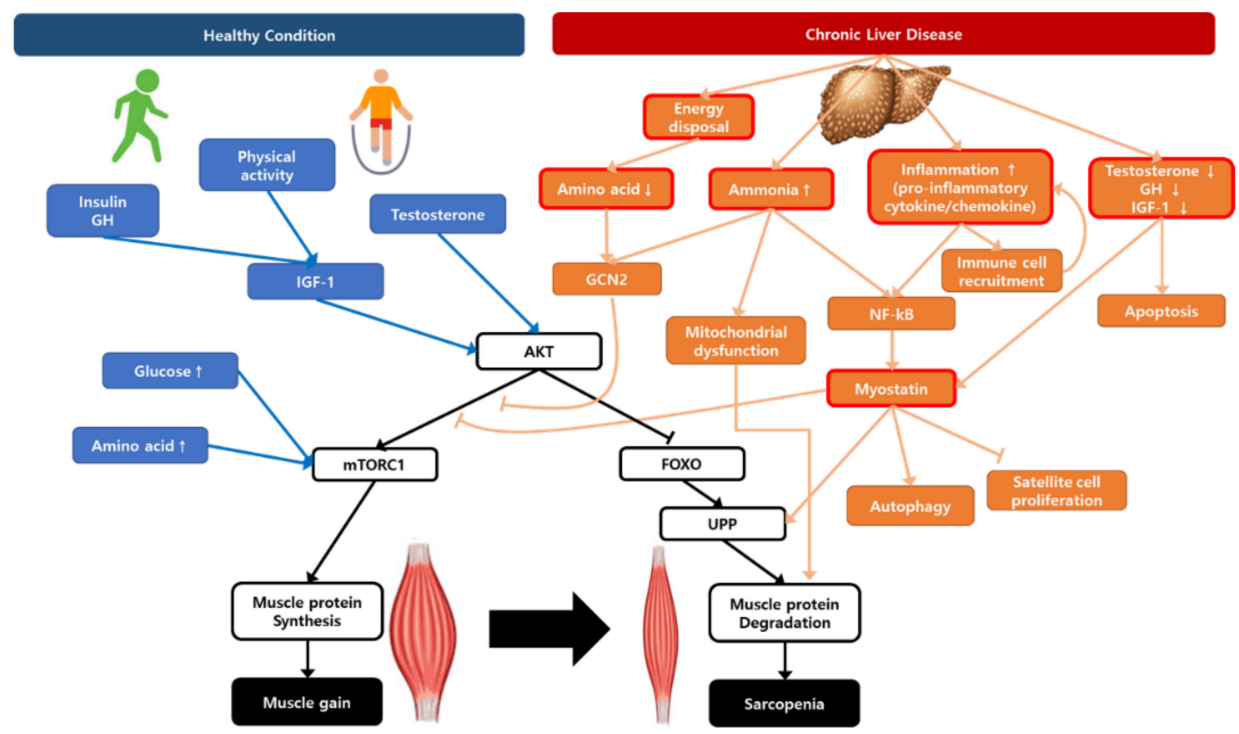

Figure 1. A schematic representation illustrating the regulation of muscle protein synthesis and degradation with the contribution of chronic liver disease to sarcopenia. AKT, protein kinase B; FOXO, Forkhead box O; GCN2, general control non-depressed 2; GH, growth hormone; IGF-1, insulin growth factor-1; mTORC1, mammalian target of rapamycin complex 1 ; NF- $\mathrm{kB}$, nuclear factor- $\mathrm{k}$; UPP, ubiquitin-proteasome pathway.

\subsection{Alterations in the Protein Turnover}

The balance between protein synthesis and degradation in skeletal muscles ensures the maintenance of protein turnover [23]. Skeletal muscle protein turnover can be regulated by several factors, including food intake, fasting, endocrine changes (i.e., insulin levels and resistance, insulin-like growth factor 1 (IGF-1), testosterone, and corticosteroids), myostatin, cytokines, and physical activity [24,25]. Some key molecular pathways that explain muscle protein turnover include the following: Akt-mediated mammalian target of rapamycin complex 1 (mTORC1) signaling, satellite cell signaling, and ubiquitin-proteasome signaling pathways [26,27]. Muscle mass is positively regulated via mTORC1 with several factors, such as growth factors, insulin or IGF-1, and energy status (glucose and amino acids) [28]. In addition, satellite cell signaling pathways contribute to muscle regeneration and growth via myonuclear accretion [29]. Interleukin 6 (IL-6) may induce satellite cell proliferation and the IGF-1 that is required for a growth stimulus activates the IGF-1-Akt pathway in satellite cells, both of which results in muscle hypertrophy [30,31]. Myostatin, which is a member of the transforming growth factor $\beta$ (TGF $\beta$ ) superfamily, negatively regulates the satellite cell activation and self-renewal that contributes to muscle protein degradation via inhibition of the Akt pathway for protein synthesis and an increase in the ubiquitinproteasome system to cause muscle atrophy [32,33]. Myostatin has been observed as 
a regulator of the catabolic pathway in skeletal muscle via the ubiquitin-proteasome and autophagy-lysosome pathways. Additionally, it has been shown to downregulate the Akt/forkhead box O (FOXO; transcription factor) pathway, causing muscle atrophy through the expression of atrophy-related genes (atrogenes) [33].

In patients with chronic liver diseases, controversial results from whole-body turnover studies have been published. As expected, some previous studies indicated that muscle wasting in cirrhosis could occur due to the decrease in muscle protein synthesis using different methods of arteriovenous exchanges and a whole-body trace [34-36]. However, other whole-body turnover studies with phenylalanine and leucine labeling reported that muscle protein turnover increased or remained unchanged [37,38]. These contradictory observations may be attributed to the lack of homogeneity in the methodology and clinical characteristics, including the etiology, age, and severity of liver diseases [15].

\subsection{Hyperammonemia}

Hyperammonemia, which is the increase in blood ammonia, in advanced liver diseases is a result of liver dysfunction accompanied by blood shunted around the liver and impaired ureagenesis $[39,40]$. Since skeletal muscle acts as a primary site for the depletion of extrahepatic ammonia, muscle wasting commonly occurs in patients with chronic liver diseases [39,41,42].

The mechanisms of muscle mass depletion that are related to hyperammonemia can be explained as follows. Ammonia levels in skeletal muscle are substantially elevated in patients with cirrhosis, thus resulting in the induction of the transcription factor NF- $\mathrm{kB}$ and a further increase in the myostatin expression, followed by the inhibition of myogenesis and an increase in autophagy [41,42]. Therefore, the key contribution to sarcopenia in patients with chronic liver disease is the hyperammonemia-induced upregulation of myostatin. In addition, the removal of ammonia occurs in skeletal muscles through the synthesis of glutamine, which is exchanged for branched-chain amino acids (BCAAs), such as leucine [43]. This also explains the decreased tendency of plasma BCAAs in patients with cirrhosis [44]. Mitochondrial dysfunction can also explain the contribution of hyperammonemia to the decrease in muscle protein synthesis. Because of higher ammonia levels in the muscle, cataplerosis (the removal of intermediate metabolites in the tricarboxylic acid cycle) dominantly occurs and induces a decrease in alpha-ketoglutarate, resulting in mitochondrial dysfunction [15,41]. Furthermore, hyperammonemia has been reported to induce oxidative stress by elevating the amount of reactive oxygen species (ROS) [45]. In conditions with high levels of ammonia, the generation of ROS can lead to increased amounts of carbonylated proteins and thiobarbituric acid-reactive substances in skeletal muscle [45]. Given the high prevalence of cirrhosis, the abovementioned studies suggest that ammonia-lowering approaches, NF- $\mathrm{kB}$ inhibitors, myostatin inhibitors, and anaplerotic substrates against mitochondrial dysfunction are potential therapeutics to counteract sarcopenia in chronic liver diseases.

\subsection{Energy Disposal}

Patients with advanced liver diseases, such as cirrhosis, are in an accelerated state of starvation, with increased gluconeogenesis, fat oxidation, ketogenesis, and a catabolic state [46-49]. In conditions of increased gluconeogenesis, circulating BCAAs in skeletal muscle are likely to decrease due to increased utilization as an energy source [49]. Reduced amino acid levels promote adaptive cellular homeostasis with elevated autophagy in skeletal muscles. Additionally, intracellular amino acid deprivation induces an integrated stress response that is mediated via activation of the amino acid deficiency sensor known as general control non-depressed 2 (GCN2) [50,51]. The activated sensor further phosphorylates the eukaryotic initiation factor $2 \alpha$ (eIF2 $\alpha$ ), resulting in the upregulation of the activating transcription factor 4 (ATF4), which induces the expression of Sestrin2 (stress response protein) and the sustained inhibition of mTORC1 to preserve amino acid 
levels [50,52]. Thus, the combined contribution of GCN2 and mTORC1 regulates the amino acid homeostasis and subsequently restores the global protein synthesis [50,53].

Patients with cirrhosis and hyperammonemia experience a similar condition of integrated stress response due to amino acid deprivation. However, hyperammonemia persistently activates GCN2 with an impaired translation of ATF4, which results in decreased muscle protein synthesis and impaired proteostasis [54,55]. Thus, patients with hyperammonemia may detour to alternative pathways of an adaptive integrated stress response, which is supposed to be mediated by the leucine exchanger SLC7A5/LAT1 [55,56]. The expression of SLC7A5/LAT1 was increased in patients with cirrhosis and it seems to play a role in increasing leucine uptake $[55,56]$. Subsequently, increased leucine concentration can be utilized in the mitochondria for energy output and can prevent the breakdown of GCN2-mediated protein synthesis as an adaptive response.

\subsection{Hormonal Changes}

Alterations in the endocrine system, such as hypotestosteronemia and an impaired insulin/IGF-1 pathway, are associated with an advanced liver disease, which could also contribute to muscle wasting [57]. Up to $90 \%$ of men with cirrhosis exhibit reduced serum testosterone, which is proportional to the decrease in liver function [58,59]. Additionally, testosterone deficiency has been shown to be an independent clinical biomarker in liver cirrhosis, and lower levels of testosterone have been identified in sarcopenic patients with cirrhosis compared to those without sarcopenia $[58,60]$. Hypogonadism, an abnormality in the hypothalamic-pituitary-gonadal axis, is involved in sarcopenia and chronic liver disease and contributes to low testosterone levels, further increasing mortality [61]. Since the anabolic influence of testosterone is well known and important in skeletal muscles, testosterone might reverse sarcopenia via multiple signaling pathways, including the suppression of myostatin and muscle cell apoptosis and the stimulation of proliferation pathways in muscle remodeling [62].

Growth hormone (GH) deficiency is correlated with fatty liver disease and the impairment of cell metabolism, which contributes to the further development of chronic liver disease [63]. GH primarily regulates the production of IGF-1, and the anabolic effect on skeletal muscles arises from both GH and IGF-1 [64]. Besides low serum levels of testosterone, a decreased IGF-1 level has been demonstrated as one of the potential risk factors for sarcopenia because IGF-1 contributes to the proliferation of satellite cells and increases muscle protein synthesis via the activation of the Akt/mTORC1 signaling pathway [65-67]. Furthermore, IGF-1 inhibits the proteolysis and activation of muscle-atrophy-related ubiquitin ligases, such as atrogin-1 (MAFbx) and MuRF-1 [68]. In elderly European men aged $\geq 70$ years, low baseline IGF-1 was related to a greater reduction in gait speed; however, it is necessary to identify whether the replacement of IGF- 1 is effective and safe to reverse sarcopenia in randomized controlled studies [69].

\subsection{Inflammation, NAFLD, and Obesity}

NAFLD is a common liver disease worldwide that can subsequently progress to nonalcoholic steatohepatitis (NASH), liver fibrosis, cirrhosis, and hepatocellular carcinoma [70]. In particular, NASH is characterized by hepatic steatosis, inflammation, and liver cell damage [71]. In addition to chronic inflammation, which is currently observed to have a direct relationship with the severity of NAFLD, insulin resistance and physical inactivity are important risk factors that are related to the development of both sarcopenia and NAFLD [11,72]. Hepatic lipotoxicity and non-liver factors, such as inflammation in adipose tissues, are linked to the elevation of proinflammatory cytokines and chemokines as key markers of NASH, such as tumor necrosis factor $\alpha$ (TNF- $\alpha$ ), IL-6, chemokine CC ligand-2, and C-reactive protein [72-74]. Following adipocyte enlargement in NAFLD, macrophage recruitment and polarization in the proinflammatory state in adipose tissues increase various proinflammatory signals, such as adipokines, contributing to the progression of NAFLD $[75,76]$. Among the inflammatory cytokines, TNF- $\alpha$ plays a key role in the 
alteration of muscle protein turnover in patients with liver disease [77-79]. TNF- $\alpha$ may alter the phosphorylation of the mTORC1 pathway, thus decreasing muscle protein synthesis, and might also induce the ubiquitin-proteasome system and the expression of atrogin-1, resulting in muscle protein breakdown [77-80]. Furthermore, TNF- $\alpha$-induced skeletal muscle atrophy could be explained by the ceramide accumulation, which is related to sphingolipid metabolism, and by the activation of NF- $\mathrm{kB}$ due to ROS elevation, which increases muscle protein degradation [81-83]. Altogether, the elevation of circulating inflammatory cytokines may contribute to muscle wasting in liver diseases, and decreasing cytokine levels might be a pharmacological approach to attenuate the loss of skeletal muscle mass.

Obesity is correlated with increased fatty acids, which causes oxidative stress and autophagy, along with the accumulation of lipid intermediates in skeletal muscles [84-86]. The accumulation of lipid intermediates, including diacylglycerol and ceramides, into the skeletal muscle (termed myosteatosis) can result in insulin resistance and mitochondrial dysfunction via impaired $\beta$-oxidation capacity [84-86]. Myosteatosis can lead to muscle atrophy, and the extent of lipid infiltration is negatively correlated with muscle function and regeneration $[87,88]$. Sarcopenic obesity is characterized by the accumulation of excessive adipose tissues, along with a decline in lean body mass [89]. Similar to myosteatosis, obese adipocytes induce the accumulation of proinflammatory immune cells, including macrophages and lymphocytes, as well as the abnormal production of diverse adipokines, which leads to the development of local proinflammatory conditions [89]. Leptin, one of the secreted adipokines from inflamed adipose tissue, contributes to the loss of skeletal muscle [90]. Furthermore, inflammatory cytokines of TNF- $\alpha$ and IL-6 induce insulin resistance via inhibition of the insulin receptor activity and signaling, along with decreased glucose uptake [91]. An increased level of leptin stimulates the production of TNF- $\alpha$ and IL-6, resulting in a vicious cycle [89]. Other obesity-induced inflammatory factors include resistin and retinol-binding protein 4 , which inhibits insulin signaling and contributes to insulin resistance, respectively [92-94]. In addition, obesity can induce a decreased level of fibroblast growth factor 21 and adiponectin, which results in decreased insulin signaling and $\beta$-oxidation in the liver $[95,96]$. Therefore, obesity could be a crucial factor for the complex mechanisms of pathophysiology between sarcopenia and NAFLD [97].

Altogether, intramuscular lipids have detrimental effects on muscle function, including mitochondrial dysfunction, oxidative stress that contributes to lipotoxic conditions, and insulin resistance, along with the release of proinflammatory myokines. Therefore, in a vicious cycle of inflammation, the exacerbated inflammation in adipose tissues and skeletal muscles triggers the development of sarcopenic obesity and NAFLD. To the best of our knowledge, the effects of lipid derivatives in patients with chronic liver disease and sarcopenia have not yet been studied.

\section{Current and Emerging Treatment Options for Sarcopenia in Chronic Liver Disease}

In recent decades, several drugs have been investigated in clinical trials to counteract sarcopenia, but no pharmacologically effective therapeutics have been approved to date. However, current and emerging treatment options for sarcopenia have been reported to be under development. In February 2021, a manual search from the Clinicaltrials.gov database (accessed on 1 February 2021) yielded several published interventional clinical trials related to sarcopenia and the potential expanded use with mostly late-phase studies (Table S1). In addition, the list of clinical trials studying therapeutic interventions for sarcopenia in chronic liver disease is provided in Table 1, which mostly consists of dietary supplements and/or behavioral interventions. Unfortunately, there is only one registered interventional clinical trial of a pharmacological treatment option using testosterone, indicating that the development of a new drug is urgently needed (Table 1). The following section discusses an update on the potential pharmacological treatment options for the treatment of sarcopenia with chronic liver diseases. 
Table 1. Current and emerging therapeutic interventions for sarcopenia with chronic liver diseases observed in clinical trials.

\begin{tabular}{|c|c|c|c|c|c|c|c|c|c|}
\hline \multirow{2}{*}{$\begin{array}{c}\text { Target or } \\
\text { Mechanism } \\
\text { of Action }\end{array}$} & \multirow{2}{*}{ Intervention } & \multirow{2}{*}{$\begin{array}{l}\text { Sponsor/ } \\
\text { Collaborator }\end{array}$} & \multirow{2}{*}{$\begin{array}{l}\text { Clinical } \\
\text { Phase }\end{array}$} & \multirow{2}{*}{ Indication } & \multirow{2}{*}{ Status } & \multirow{2}{*}{$\begin{array}{c}\text { NCT } \\
\text { Number }\end{array}$} & \multicolumn{2}{|c|}{ Year } & \multirow{2}{*}{ Title } \\
\hline & & & & & & & Start & End & \\
\hline Testosterone & $\begin{array}{l}\text { Testosterone } \\
\text { undecanoate }\end{array}$ & $\begin{array}{l}\text { Institute of } \\
\text { Liver and } \\
\text { Biliary } \\
\text { Sciences, } \\
\text { India }\end{array}$ & NA & $\begin{array}{l}\text { Liver } \\
\text { cirrhosis }\end{array}$ & Recruiting & NCT03995251 & 2019 & 2020 & $\begin{array}{l}\text { Efficacy and Safety of } \\
\text { Testosterone Therapy in } \\
\text { Improving Sarcopenia in } \\
\text { Men with Cirrhosis: A } \\
\text { Randomized Controlled Trial }\end{array}$ \\
\hline Behavior & Exercise & $\begin{array}{l}\text { University } \\
\text { of California, } \\
\text { San Fran- } \\
\text { cisco/Johns } \\
\text { Hopkins } \\
\text { University, } \\
\text { Duke } \\
\text { University }\end{array}$ & NA & $\begin{array}{l}\text { End-stage } \\
\text { liver disease, } \\
\text { sarcopenia, } \\
\text { liver } \\
\text { cirrhosis }\end{array}$ & Completed & NCT02367092 & 2016 & 2019 & $\begin{array}{l}\text { Exercise Intervention in } \\
\text { Liver Transplant Patients }\end{array}$ \\
\hline Behavior & Exercise & $\begin{array}{l}\text { Memorial } \\
\text { Hospital } \\
\text { Groups }\end{array}$ & NA & $\begin{array}{l}\text { End-stage } \\
\text { liver disease, } \\
\text { chronic liver } \\
\text { failure, } \\
\text { sarcopenia }\end{array}$ & Completed & NCT04546048 & 2018 & 2019 & $\begin{array}{l}\text { The Early Strength Training } \\
\text { Exercise Therapy in Liver } \\
\text { Recipients: Protocol for an } \\
\text { Observational Feasibility } \\
\text { Trial }\end{array}$ \\
\hline Behavior & $\begin{array}{l}\text { Pulmonary } \\
\text { rehabilita- } \\
\text { tion exercise, } \\
\text { home-based } \\
\text { exercise }\end{array}$ & Mayo Clinic & NA & $\begin{array}{l}\text { End-stage } \\
\text { liver disease }\end{array}$ & Recruiting & NCT03266575 & 2018 & Ongoing & $\begin{array}{l}\text { Does Pulmonary } \\
\text { Rehabilitation Improve } \\
\text { Frailty and Sarcopenia in } \\
\text { End-Stage Liver Disease? }\end{array}$ \\
\hline $\begin{array}{c}\text { Dietary } \\
\text { supplement }\end{array}$ & $\begin{array}{l}\text { Amino acid } \\
\text { infusion }\end{array}$ & $\begin{array}{l}\text { Rigshospitalet, } \\
\text { Denmark/ } \\
\text { Hvidovre } \\
\text { University } \\
\text { Hospital }\end{array}$ & NA & Cirrhosis & Completed & NCT02132962 & 2014 & 2015 & Sarcopenia and Cirrhosis \\
\hline $\begin{array}{c}\text { Dietary } \\
\text { supplement }\end{array}$ & BCAA & $\begin{array}{l}\text { Puerta de } \\
\text { Hierro } \\
\text { University } \\
\text { Hospital }\end{array}$ & NA & Sarcopenia & Completed & NCT04073693 & 2017 & 2019 & $\begin{array}{l}\text { Characterization of the } \\
\text { Nutritional Status in the } \\
\text { Patient with Liver Cirrhosis } \\
\text { and Impact of a Nutritional } \\
\text { Intervention with Nutritional } \\
\text { Supplements with BCAA vs. } \\
\text { Standard Treatment in the } \\
\text { Subgroup of Patients with } \\
\text { Sarcopenia }\end{array}$ \\
\hline $\begin{array}{c}\text { Dietary } \\
\text { supplement }\end{array}$ & BCAA & $\begin{array}{l}\text { Dayanand } \\
\text { Medical } \\
\text { College and } \\
\text { Hospital }\end{array}$ & 4 & $\begin{array}{c}\text { Liver } \\
\text { cirrhosis }\end{array}$ & Recruiting & NCT03633279 & 2018 & 2020 & $\begin{array}{l}\text { Treatment of Sarcopenia } \\
\text { Improves the Muscle Mass } \\
\text { and Muscle Strength of } \\
\text { Patients with Liver } \\
\text { Cirrhosis-Child C: A } \\
\text { Randomized Double Blind } \\
\text { Control Trial }\end{array}$ \\
\hline $\begin{array}{c}\text { Dietary } \\
\text { supplement }\end{array}$ & BCAA & $\begin{array}{l}\text { Institute of } \\
\text { Liver and } \\
\text { Biliary } \\
\text { Sciences, } \\
\text { India }\end{array}$ & NA & $\begin{array}{c}\text { Chronic liver } \\
\text { disease }\end{array}$ & Recruiting & NCT04246918 & 2020 & Ongoing & $\begin{array}{l}\text { Effect of Branched Chain } \\
\text { Amino Acids } \\
\text { Supplementation on Muscle } \\
\text { Mass, Muscle Quality, and } \\
\text { Molecular Markers of Muscle } \\
\text { Regeneration in Patients } \\
\text { With Chronic Liver Disease: } \\
\text { A Randomized Controlled } \\
\text { Trial }\end{array}$ \\
\hline $\begin{array}{c}\text { Dietary } \\
\text { supplement }\end{array}$ & HMB & $\begin{array}{l}\text { University } \\
\text { of Roma La } \\
\text { Sapienza }\end{array}$ & NA & Sarcopenia & Completed & NCT03234920 & 2015 & 2018 & $\begin{array}{l}\text { Effects of } \beta \text {-Hydroxy- } \beta \text { - } \\
\text { methylbutyrate (HMB) } \\
\text { Supplementation after Liver } \\
\text { Transplantation: } \\
\text { Randomized and Controlled } \\
\text { Pilot Study }\end{array}$ \\
\hline $\begin{array}{c}\text { Dietary } \\
\text { supplement }\end{array}$ & $\mathrm{CaHMB}$ & $\begin{array}{l}\text { Shanghai } \\
\text { Zhongshan } \\
\text { Hospital }\end{array}$ & NA & $\begin{array}{l}\text { Sarcopenia, } \\
\text { liver } \\
\text { cirrhosis }\end{array}$ & Unknown & NCT03605147 & 2018 & 2019 & $\begin{array}{l}\text { The Effect of Calcium } \beta \text { - } \\
\text { Hydroxy- } \beta \text {-methylbutyrate } \\
\text { Supplementation in } \\
\text { Sarcopenia in Liver Cirrhosis: } \\
\text { A Randomized Double-Blind } \\
\text { Controlled Trial }\end{array}$ \\
\hline $\begin{array}{c}\text { Dietary } \\
\text { supplement }\end{array}$ & HMB & $\begin{array}{l}\text { University } \\
\text { of Roma La } \\
\text { Sapienza }\end{array}$ & NA & $\begin{array}{l}\text { Sarcopenia, } \\
\text { liver } \\
\text { cirrhosis }\end{array}$ & Recruiting & NCT03892070 & 2019 & 2020 & $\begin{array}{l}\beta \text {-Hydroxy- } \beta \text { - } \\
\text { methylbutyrate } \\
\text { Supplementation and } \\
\text { Physical Activity in Liver } \\
\text { Cirrhosis: A Controlled Trial }\end{array}$ \\
\hline
\end{tabular}


Table 1. Cont.

\begin{tabular}{|c|c|c|c|c|c|c|c|c|c|}
\hline \multirow{2}{*}{$\begin{array}{c}\text { Target or } \\
\text { Mechanism } \\
\text { of Action }\end{array}$} & \multirow{2}{*}{ Intervention } & \multirow{2}{*}{$\begin{array}{c}\text { Sponsor/ } \\
\text { Collaborator }\end{array}$} & \multirow{2}{*}{$\begin{array}{c}\text { Clinical } \\
\text { Phase }\end{array}$} & \multirow{2}{*}{ Indication } & \multirow{2}{*}{ Status } & \multirow{2}{*}{$\begin{array}{c}\text { NCT } \\
\text { Number }\end{array}$} & \multicolumn{2}{|c|}{ Year } & \multirow{2}{*}{ Title } \\
\hline & & & & & & & Start & End & \\
\hline $\begin{array}{c}\text { Dietary } \\
\text { supplement }\end{array}$ & $\begin{array}{l}\text { Ensure Plus } \\
\text { Advance, } \\
\text { Ensure High } \\
\text { Protein }\end{array}$ & $\begin{array}{l}\text { Instituto } \\
\text { Aragones de } \\
\text { Ciencias de } \\
\text { la Salud/ } \\
\text { Refbio2: } \\
\text { Trans- } \\
\text { Pyrenean } \\
\text { Cooperation } \\
\text { Network for } \\
\text { Biomedical } \\
\text { Research }\end{array}$ & NA & $\begin{array}{l}\text { Sarcopenia, } \\
\text { liver } \\
\text { cirrhosis }\end{array}$ & $\begin{array}{l}\text { Active, not } \\
\text { recruiting }\end{array}$ & NCT03285217 & 2017 & 2019 & $\begin{array}{l}\text { HMB for Denutrition in } \\
\text { Patients with Cirrhosis } \\
\text { (HEPATIC) }\end{array}$ \\
\hline $\begin{array}{c}\text { Dietary } \\
\text { supplement }\end{array}$ & $\begin{array}{l}\text { Fresubin } \\
\text { energy } \\
\text { (dietary } \\
\text { protein } \\
\text { energy } \\
\text { supplement) }\end{array}$ & $\begin{array}{l}\text { Medical } \\
\text { University } \\
\text { of Graz }\end{array}$ & NA & $\begin{array}{l}\text { Sarcopenia, } \\
\text { liver } \\
\text { cirrhosis }\end{array}$ & Recruiting & NCT03080129 & 2017 & Ongoing & $\begin{array}{l}\text { Microbiome and Sarcopenia } \\
\text { in Patients with Liver } \\
\text { Cirrhosis: A Prospective } \\
\text { Controlled Cohort Study }\end{array}$ \\
\hline $\begin{array}{c}\text { Dietary } \\
\text { supplement }\end{array}$ & $\begin{array}{l}\text { Medically } \\
\text { tailored } \\
\text { meals, } \\
\text { protein } \\
\text { supplements }\end{array}$ & $\begin{array}{l}\text { University } \\
\text { of Michigan }\end{array}$ & NA & $\begin{array}{l}\text { Sarcopenia, } \\
\text { liver } \\
\text { cirrhosis, } \\
\text { hepatic } \\
\text { encephalopa- } \\
\text { thy, } \\
\text { ascites }\end{array}$ & Recruiting & NCT04675775 & 2021 & Ongoing & $\begin{array}{l}\text { Medically Tailored Meals to } \\
\text { Prevent Recurrent Hepatic } \\
\text { Encephalopathy: The } \\
\text { BRAINFOOD Pilot Trial }\end{array}$ \\
\hline $\begin{array}{l}\text { Multifactorial } \\
\text { intervention }\end{array}$ & $\begin{array}{l}\text { Home } \\
\text { exercise, } \\
\text { BCAA sup- } \\
\text { plements, } \\
\text { multispecies } \\
\text { probiotic }\end{array}$ & $\begin{array}{c}\text { Fundació } \\
\text { Institut de } \\
\text { Recerca de } \\
\text { l’Hospital de } \\
\text { la Santa } \\
\text { Creu i Sant } \\
\text { Pau }\end{array}$ & NA & $\begin{array}{l}\text { Sarcopenia, } \\
\text { liver } \\
\text { cirrhosis, } \\
\text { frailty } \\
\text { syndrome } \\
\text { (FS) }\end{array}$ & Recruiting & NCT04243148 & 2020 & Ongoing & $\begin{array}{l}\text { Frailty in Patients with } \\
\text { Cirrhosis: Prognostic Value } \\
\text { of the Phase Angle in } \\
\text { Hospitalized Patients and } \\
\text { Effect of a Multifactorial } \\
\text { Intervention (Home Exercise, } \\
\text { Branched-chain Amino } \\
\text { Acids, and Probiotics) }\end{array}$ \\
\hline $\begin{array}{l}\text { Multifactorial } \\
\text { intervention }\end{array}$ & $\begin{array}{c}\text { Physical } \\
\text { training } \\
\text { program, } \\
\text { behavioral } \\
\text { modification } \\
\text { therapy, } \\
\text { nutritional } \\
\text { consultation }\end{array}$ & $\begin{array}{l}\text { University } \\
\text { of Arkansas }\end{array}$ & NA & $\begin{array}{l}\text { End-stage } \\
\text { liver disease, } \\
\text { liver } \\
\text { transplant, } \\
\text { sarcopenia, } \\
\text { cirrhosis }\end{array}$ & Completed & NCT02776553 & 2016 & 2020 & $\begin{array}{l}\text { A Physical Activity Program } \\
\text { in End-Stage Liver Disease: } \\
\text { Pilot Study Assessing } \\
\text { Changes in Physical Fitness, } \\
\text { Sarcopenia, and the } \\
\text { Metabolic Profile }\end{array}$ \\
\hline
\end{tabular}

Data were presented in the Clinicaltrials.gov on 1 February 2021. Abbreviation: BCAA, branched chain amino acid; HMB, $\beta$-hydroxy- $\beta$ methylbutyrate; NA, not applicable.

\subsection{Hormonal Treatment}

Since testosterone deficiency is a common feature in advanced liver diseases, a previous study reported that testosterone treatment can reduce fat mass and hemoglobin A1c and can increase muscle and bone mass, along with hemoglobin elevation in patients with cirrhosis [61]. Testosterone treatment particularly increases the expression of androgen receptors, resulting in muscle cell growth and the differentiation for muscle protein synthesis [98]. In addition, testosterone drives the upregulation of IGF-1 via the Akt pathway to enhance beneficial effects on muscle growth via the proliferation of satellite cells $[62,99]$. By means of another pathway, testosterone replacement therapy contributes to the myostatin downregulation, further suppressing apoptosis in skeletal muscles [62]. However, clear molecular evidence of testosterone treatment should be obtained via further research, and adverse events, such as cardiovascular diseases, fluid retention, gynecomastia, sleep apnea, and the progression of prostatic diseases, need to be cautiously monitored [100]. Therefore, long-term confirmatory studies are needed to prove its efficacy and safety in sarcopenic patients with chronic liver diseases [101].

As previously mentioned, GH deficiency is correlated with the development of chronic liver diseases, which supports the hypothesis that GH replacement treatment can improve muscle mass by increasing serum IGF-1 levels and IGF binding protein 3 with the activation of the mTORC1 signaling pathway [102-104]. GH replacement therapy may also involve antioxidant defenses through the activation of mitochondrial biogenesis pathways [104]. However, GH supplementation may cause a high rate of adverse reactions, including 
worsening ascites and edema, with limited applicability due to its high cost $[104,105]$. Therefore, the clinical utility of GH replacement treatment needs to be confirmed in further studies to identify its safety and efficacy in clinical use.

\subsection{Myostatin and Activin Receptor}

Myostatin is an important target in various studies because of its detrimental effects on muscle protein synthesis [106]. Myostatin inhibits the differentiation and growth of skeletal muscle cells by binding to the activin type IIB (ACVRIIB) receptor, which subsequently inhibits the differentiation of myoblasts and the mTORC1 signaling pathway [107]. Stamulumab (MYO-029), a myostatin inhibitor studied in human trials, is a recombinant human antibody that neutralizes myostatin, which inhibits its binding to ACVRIIB. However, further development was stopped due to the limited efficacy on muscle strength in phase 2 clinical trials in patients with muscular dystrophy. Landogrozumab (LY-2495655), another myostatin inhibitor as a humanized monoclonal antibody under review, also binds to myostatin and neutralizes its activity. Landogrozumab has been shown to increase total lean body mass with a fat mass reduction in older weak fallers and to improve general physical performance [108]. Clinical trials of landogrozumab treatment for muscle atrophy in patients with hip arthroplasty identified improvement in muscle mass; however, the lean body mass did not meet the threshold [109]. Trevogrumab (REGN1033) is another human monoclonal antibody that targets myostatin for the treatment of sarcopenia, where its safety and efficacy are still being assessed after the completion of phase 2 clinical trials [110].

Ramatercept (ACE-031), an ACVRIIB/FC recombinant fusion protein, binds to the ligands (e.g., myostatin, activins, and growth differentiation factor 11) of ACVRIIB to inhibit the endogenous receptor binding. Despite its award of orphan designation and accelerated review by the U.S. Food and Drug Administration (FDA), further development for the treatment of muscular dystrophy was stopped after completion in 2011 because of safety concerns, such as minor nosebleeds, gum bleeding, and/or small dilated blood vessels within the skin [111,112]. ACE-083, as an alternative form of ACE-031, is a locally acting and follistatin-based fusion protein that binds and acts by neutralizing myostatin, activins, and growth differentiation factor 11 [113]. Follistatin is known to improve muscle growth and function by preventing ligands from binding to receptors [114]. A first-in-human phase I clinical trial of ACE-083 demonstrated that it was well tolerated and produced increased muscle volume in healthy volunteers, which provides evidence for the potential treatment of various neuromuscular disorders, along with the need for further investigation of its efficacy and safety [115].

ACVRIIB is another potentially effective target for the development of treatments for sarcopenia. Bimagrumab (BYM-338), a human monoclonal antibody targeting ACVRIIB, was designed to competitively bind to ACVRIIB with higher affinity than its ligands. Breakthrough therapy designation was granted to bimagrumab in 2013 by the FDA for sporadic inclusion body myositis, which is characterized by inflammatory myopathy and progressive skeletal muscle atrophy. A preclinical study showed that bimagrumab increased the differentiation of myoblasts and inhibited the activity of myostatin or activin A, thus resulting in the improvement of skeletal muscle mass in mice [116]. A phase 2 clinical trial of bimagrumab in elderly patients with sarcopenia and limited mobility showed that bimagrumab improved muscle growth/function and mobility [117]. However, other late phases of clinical trials for bimagrumab treatment increased skeletal muscle mass in one study but observed no significant effects on functional capacity in sarcopenic patients with chronic obstructive pulmonary disease or sporadic inclusion body myositis $[118,119]$. In addition, the clinical use of ACVRIIB inhibitors may cause several adverse events, including muscle spasms, diarrhea, and acne [117-119]. Although there are many past and ongoing studies showing that the inhibition of the myostatin/ACVRIIB signaling pathway may counteract sarcopenia, the combination approaches with nutritional and/or physical activity could be a more promising and effective treatment for sarcopenia $[110,120]$. While this therapeutic approach has not yet been studied in sarcopenic patients with chronic 
liver diseases, the current status of research indicates that myostatin/ACVRIIB signaling inhibition can be an emerging treatment option for muscular dystrophy.

\subsection{Ammonia-Lowering Treatment}

As previously discussed, hyperammonemia is a feature of patients with cirrhosis that contributes to abnormal skeletal muscle proteostasis. Although the clinical utility of ammonia-lowering treatment is expected to be effective, whether this therapeutic approach can improve proteostasis and reverse sarcopenia in chronic liver disease is uncertain. A preclinical study showed that ammonia-lowering treatment significantly increased lean body mass and improved grip strength and skeletal muscle growth [121]. Perturbed molecular actions due to hyperammonemia were also improved with the reduction of myostatin expression and autophagy markers and with the reversal of GCN2/eIF2 $\alpha$ phosphorylation [121]. L-ornithine L-aspartate can be an adequate option for ammonia-lowering treatment for patients with cirrhosis suffering from hepatic encephalopathy through the improvement of skeletal muscle growth and function, as supported by several randomized clinical trials and meta-analyses [122]. In addition, nutraceuticals, such as BCAA, L-carnitine, omega-3 polyunsaturated fatty acids, zinc, and vitamin $\mathrm{D}$, may provide a promising standard of care with beneficial improvements in muscle homeostasis for sarcopenia in chronic liver disease [123]. Confirmation of these ammonia-lowering approaches for the treatment of sarcopenia in chronic liver disease is necessary for powered and wellcontrolled clinical trials to provide further evidence of efficacy.

\subsection{Clinical Nutrition}

In cirrhotic patients, the rates of both hepatic glucose production and oxidation are decreased owing to a depletion of hepatic glycogen, although gluconeogenesis is increased [124,125]. Thus, patients are susceptible to an accelerated state of starvation after an overnight fast [49]. Furthermore, impaired protein turnover and decreased plasma levels of essential fatty acids are observed in cirrhosis [126,127]. Therefore, the European Society for Clinical Nutrition and Metabolism (ESPEN) guideline recommends that the starvation period be kept short in cirrhosis to ameliorate protein turnover by taking 3-5 meals/day and a late evening snack [128]. A late evening snack has been shown to improve the nitrogen balance and decreased lipid oxidation, regardless of the composition or type of formulation used $[129,130]$. It is also suggested that cirrhotic patients with sarcopenia should include an optimal energy intake of 30-35 kcal/ $\mathrm{kg} /$ day and a target protein intake of $1.2-1.5 \mathrm{~g} / \mathrm{kg} /$ day [128]. To overcome protein depletion in cirrhotic patients with sarcopenia, including those with sarcopenic obesity, increased protein intake can improve protein anabolism and the status of total body protein [128,131,132]. In addition, in cirrhotic patients, including those with advanced cirrhosis and a previous episode of hepatic encephalopathy, a long-term BCAA supplementation (0.20-0.25 g/ $\mathrm{kg} /$ day) had beneficial effects on protein metabolism, resulting in improved muscle mass, as well as minimal hepatic encephalopathy [133-136]. Since a specific nutritional intervention is needed in sarcopenic patients with chronic liver disease, multidisciplinary nutrition care should be implemented in the metabolic management of patients to achieve nutritional goals.

\subsection{Regenerative Therapeutic Approach: Mitochondrial Restoration and Anti-Inflammation}

Since the current pharmaceutical options for sarcopenia in chronic liver diseases may be ineffective and restricted in terms of the available clinical evidence, novel therapeutic approaches are necessary to improve mitochondrial function, reduce chronic inflammation, and induce muscle tissue regeneration, thus leading to increased muscle growth and function. Considering the abovementioned etiology of sarcopenia, regenerative medicine and stem cell therapy are potential alternatives for sarcopenia alleviation because of their ability to change the proinflammatory microenvironment into regenerating and reinnervating conditions by producing anti-inflammatory cytokines [137]. Mesenchymal stem cell transplantation has been shown to modulate immunological effects through the production of 
anti-inflammatory cytokines, including IL-10 and IL-13, and to stimulate neurosupportive effects by secreting factors including basic fibroblast growth factor and vascular endothelial growth factor [138-142]. In addition, mesenchymal stem cells may restore mitochondrial function in skeletal muscle via the mediation of mitochondrial transplantation [143]. However, stem cell transplantation has many restrictive hurdles to overcome (e.g., controversial safety and efficacy, ethics, pharmaceutical manufacturing process, and quality control); the secretome of stem cells that houses the important anti-inflammatory agents may provide a more promising option than the direct use of stem cells [137]. Nevertheless, extensive research through preclinical and clinical studies with a larger patient population is still required to determine its efficacy and safety as a potential therapeutic option for sarcopenia in chronic liver disease.

\section{Conclusions}

Sarcopenia in chronic liver disease is a complicated and multifactorial disease with various contributing factors. Several clinical studies on sarcopenia in chronic liver diseases have examined the effects of nutritional supplements, behavioral interventions, and their combinations, but pharmacological therapeutic approaches have rarely been studied. Since the attempt of a nutritional approach is not always effective in improving clinical outcomes, behavioral intervention is practically impossible for bedridden patients who may need these approaches the most. Therefore, there is an urgent need to develop potential treatment options, including an ammonia-lowering approach that blocks the myostatinactivin receptor pathway, as well as hormonal therapy, regenerative therapeutics, and their combinations, to prevent and reverse sarcopenia.

Supplementary Materials: The following are available online at https:/ / www.mdpi.com/2075-172 9/11/3/250/s1, Table S1: Current and emerging treatment options for sarcopenia that have been observed in clinical trials.

Funding: This research received no external funding.

Institutional Review Board Statement: Not applicable.

Informed Consent Statement: Not applicable.

Data Availability Statement: Not applicable.

Conflicts of Interest: The author declares no conflict of interest.

\section{References}

1. Cruz-Jentoft, A.J.; Bahat, G.; Bauer, J.; Boirie, Y.; Bruyere, O.; Cederholm, T.; Cooper, C.; Landi, F.; Rolland, Y.; Sayer, A.A.; et al. Sarcopenia: Revised European consensus on definition and diagnosis. Age Ageing 2019, 48, 601. [CrossRef]

2. Rosenberg, I.H. Sarcopenia: Origins and clinical relevance. J. Nutr. 1997, 127, 990S-991S. [CrossRef] [PubMed]

3. Morley, J.E.; Abbatecola, A.M.; Argiles, J.M.; Baracos, V.; Bauer, J.; Bhasin, S.; Cederholm, T.; Coats, A.J.; Cummings, S.R.; Evans, W.J.; et al. Sarcopenia with limited mobility: An international consensus. J. Am. Med. Dir. Assoc. 2011, 12, $403-409$. [CrossRef] [PubMed]

4. Chen, L.K.; Liu, L.K.; Woo, J.; Assantachai, P.; Auyeung, T.W.; Bahyah, K.S.; Chou, M.Y.; Chen, L.Y.; Hsu, P.S.; Krairit, O.; et al. Sarcopenia in Asia: Consensus report of the Asian Working Group for Sarcopenia. J. Am. Med. Dir. Assoc. 2014, 15, 95-101. [CrossRef] [PubMed]

5. $\quad$ Delmonico, M.J.; Harris, T.B.; Visser, M.; Park, S.W.; Conroy, M.B.; Velasquez-Mieyer, P.; Boudreau, R.; Manini, T.M.; Nevitt, M.; Newman, A.B.; et al. Longitudinal study of muscle strength, quality, and adipose tissue infiltration. Am. J. Clin. Nutr. 2009, 90, 1579-1585. [CrossRef]

6. Cruz-Jentoft, A.J.; Baeyens, J.P.; Bauer, J.M.; Boirie, Y.; Cederholm, T.; Landi, F.; Martin, F.C.; Michel, J.P.; Rolland, Y.; Schneider, S.M.; et al. Sarcopenia: European consensus on definition and diagnosis: Report of the European Working Group on Sarcopenia in Older People. Age Ageing 2010, 39, 412-423. [CrossRef] [PubMed]

7. Shafiee, G.; Keshtkar, A.; Soltani, A.; Ahadi, Z.; Larijani, B.; Heshmat, R. Prevalence of sarcopenia in the world: A systematic review and meta- analysis of general population studies. J. Diabetes Metab. Disord. 2017, 16, 21. [CrossRef]

8. Lee, Y.H.; Jung, K.S.; Kim, S.U.; Yoon, H.J.; Yun, Y.J.; Lee, B.W.; Kang, E.S.; Han, K.H.; Lee, H.C.; Cha, B.S. Sarcopaenia is associated with NAFLD independently of obesity and insulin resistance: Nationwide surveys (KNHANES 2008-2011). J. Hepatol. 2015, 63, 486-493. [CrossRef] 
9. Hong, H.C.; Hwang, S.Y.; Choi, H.Y.; Yoo, H.J.; Seo, J.A.; Kim, S.G.; Kim, N.H.; Baik, S.H.; Choi, D.S.; Choi, K.M. Relationship between sarcopenia and nonalcoholic fatty liver disease: The Korean Sarcopenic Obesity Study. Hepatology 2014, 59, 1772-1778. [CrossRef]

10. Chung, G.E.; Kim, M.J.; Yim, J.Y.; Kim, J.S.; Yoon, J.W. Sarcopenia Is Significantly Associated with Presence and Severity of Nonalcoholic Fatty Liver Disease. J. Obes. Metab. Syndr. 2019, 28, 129-138. [CrossRef]

11. Lee, Y.H.; Kim, S.U.; Song, K.; Park, J.Y.; Kim, D.Y.; Ahn, S.H.; Lee, B.W.; Kang, E.S.; Cha, B.S.; Han, K.H. Sarcopenia is associated with significant liver fibrosis independently of obesity and insulin resistance in nonalcoholic fatty liver disease: Nationwide surveys (KNHANES 2008-2011). Hepatology 2016, 63, 776-786. [CrossRef] [PubMed]

12. Koo, B.K.; Kim, D.; Joo, S.K.; Kim, J.H.; Chang, M.S.; Kim, B.G.; Lee, K.L.; Kim, W. Sarcopenia is an independent risk factor for non-alcoholic steatohepatitis and significant fibrosis. J. Hepatol. 2017, 66, 123-131. [CrossRef]

13. Lee, M.J.; Kim, E.H.; Bae, S.J.; Kim, G.A.; Park, S.W.; Choe, J.; Jung, C.H.; Lee, W.J.; Kim, H.K. Age-Related Decrease in Skeletal Muscle Mass Is an Independent Risk Factor for Incident Nonalcoholic Fatty Liver Disease: A 10-Year Retrospective Cohort Study. Gut Liver 2019, 13, 67-76. [CrossRef] [PubMed]

14. Kim, G.; Kang, S.H.; Kim, M.Y.; Baik, S.K. Prognostic value of sarcopenia in patients with liver cirrhosis: A systematic review and meta-analysis. PLoS ONE 2017, 12, e0186990. [CrossRef] [PubMed]

15. Dasarathy, S.; Merli, M. Sarcopenia from mechanism to diagnosis and treatment in liver disease. J. Hepatol. 2016, 65, 1232-1244. [CrossRef] [PubMed]

16. Montano-Loza, A.J.; Meza-Junco, J.; Prado, C.M.; Lieffers, J.R.; Baracos, V.E.; Bain, V.G.; Sawyer, M.B. Muscle wasting is associated with mortality in patients with cirrhosis. Clin. Gastroenterol. Hepatol. 2012, 10, 166-173.e1. [CrossRef]

17. Tateyama, M.; Naoe, H.; Tanaka, M.; Tanaka, K.; Narahara, S.; Tokunaga, T.; Kawasaki, T.; Yoshimaru, Y.; Nagaoka, K.; Watanabe, T.; et al. Loss of skeletal muscle mass affects the incidence of minimal hepatic encephalopathy: A case control study. BMC Gastroenterol. 2020, 20, 371. [CrossRef]

18. Ooi, P.H.; Hager, A.; Mazurak, V.C.; Dajani, K.; Bhargava, R.; Gilmour, S.M.; Mager, D.R. Sarcopenia in Chronic Liver Disease: Impact on Outcomes. Liver Transpl. 2019, 25, 1422-1438. [CrossRef]

19. Van Vugt, J.L.; Levolger, S.; de Bruin, R.W.; van Rosmalen, J.; Metselaar, H.J.; IJzermans, J.N.M. Systematic Review and MetaAnalysis of the Impact of Computed Tomography-Assessed Skeletal Muscle Mass on Outcome in Patients Awaiting or Undergoing Liver Transplantation. Am. J. Transpl. 2016, 16, 2277-2292. [CrossRef]

20. Sinclair, M.; Poltavskiy, E.; Dodge, J.L.; Lai, J.C. Frailty is independently associated with increased hospitalisation days in patients on the liver transplant waitlist. World J. Gastroenterol. 2017, 23, 899-905. [CrossRef]

21. Van Vugt, J.L.A.; Buettner, S.; Alferink, L.J.M.; Bossche, N.; de Bruin, R.W.F.; Darwish Murad, S.; Polak, W.G.; Metselaar, H.J.; IJzermans, J.N.M. Low skeletal muscle mass is associated with increased hospital costs in patients with cirrhosis listed for liver transplantation-a retrospective study. Transpl. Int. 2018, 31, 165-174. [CrossRef] [PubMed]

22. Ohashi, K.; Ishikawa, T.; Imai, M.; Suzuki, M.; Hoshii, A.; Abe, H.; Koyama, F.; Nakano, T.; Ueki, A.; Noguchi, H.; et al. Relationship between pre-sarcopenia and quality of life in patients with chronic liver disease: A cross-sectional study. Eur. J. Gastroenterol. Hepatol. 2019, 31, 1408-1413. [CrossRef] [PubMed]

23. Millward, D.J.; Garlick, P.J.; Stewart, R.J.; Nnanyelugo, D.O.; Waterlow, J.C. Skeletal-muscle growth and protein turnover. Biochem. J. 1975, 150, 235-243. [CrossRef] [PubMed]

24. Rose, A.J.; Richter, E.A. Regulatory mechanisms of skeletal muscle protein turnover during exercise. J. Appl. Physiol. (1985) 2009, 106, 1702-1711. [CrossRef]

25. Wing, S.S.; Lecker, S.H.; Jagoe, R.T. Proteolysis in illness-associated skeletal muscle atrophy: From pathways to networks. Crit. Rev. Clin. Lab. Sci. 2011, 48, 49-70. [CrossRef]

26. Egerman, M.A.; Glass, D.J. Signaling pathways controlling skeletal muscle mass. Crit. Rev. Biochem. Mol. Biol. 2014, 49, 59-68. [CrossRef]

27. Price, S.R.; Du, J.D.; Bailey, J.L.; Mitch, W.E. Molecular mechanisms regulating protein turnover in muscle. Am. J. Kidney Dis. 2001, 37, S112-S114. [CrossRef]

28. Jewell, J.L.; Russell, R.C.; Guan, K.L. Amino acid signalling upstream of mTOR. Nat. Rev. Mol. Cell Biol. 2013, 14, 133-139. [CrossRef]

29. Pallafacchina, G.; Blaauw, B.; Schiaffino, S. Role of satellite cells in muscle growth and maintenance of muscle mass. Nutr. Metab. Cardiovasc. Dis. 2013, 23 (Suppl. S1), S12-S18. [CrossRef]

30. Yin, H.; Price, F.; Rudnicki, M.A. Satellite cells and the muscle stem cell niche. Physiol. Rev. 2013, 93, 23-67. [CrossRef]

31. Schiaffino, S.; Mammucari, C. Regulation of skeletal muscle growth by the IGF1-Akt/PKB pathway: Insights from genetic models. Skelet. Muscle 2011, 1, 4. [CrossRef]

32. McCroskery, S.; Thomas, M.; Maxwell, L.; Sharma, M.; Kambadur, R. Myostatin negatively regulates satellite cell activation and self-renewal. J. Cell Biol. 2003, 162, 1135-1147. [CrossRef]

33. Rodriguez, J.; Vernus, B.; Chelh, I.; Cassar-Malek, I.; Gabillard, J.C.; Hadj Sassi, A.; Seiliez, I.; Picard, B.; Bonnieu, A. Myostatin and the skeletal muscle atrophy and hypertrophy signaling pathways. Cell. Mol. Life Sci. 2014, 71, 4361-4371. [CrossRef] [PubMed]

34. Morrison, W.L.; Bouchier, I.A.; Gibson, J.N.; Rennie, M.J. Skeletal muscle and whole-body protein turnover in cirrhosis. Clin. Sci. 1990, 78, 613-619. [CrossRef] [PubMed] 
35. Tessari, P.; Barazzoni, R.; Kiwanuka, E.; Davanzo, G.; De Pergola, G.; Orlando, R.; Vettore, M.; Zanetti, M. Impairment of albumin and whole body postprandial protein synthesis in compensated liver cirrhosis. Am. J. Physiol. Endocrinol. Metab. 2002, 282, E304-E311. [CrossRef]

36. Tessari, P.; Kiwanuka, E.; Vettore, M.; Barazzoni, R.; Zanetti, M.; Cecchet, D.; Orlando, R. Phenylalanine and tyrosine kinetics in compensated liver cirrhosis: Effects of meal ingestion. Am. J. Physiol. Gastrointest. Liver Physiol. 2008, 295, G598-G604. [CrossRef]

37. Tessari, P.; Vettore, M.; Millioni, R.; Puricelli, L.; Orlando, R. Effect of liver cirrhosis on phenylalanine and tyrosine metabolism. Curr. Opin. Clin. Nutr. Metab. Care 2010, 13, 81-86. [CrossRef] [PubMed]

38. McCullough, A.J.; Mullen, K.D.; Tavill, A.S.; Kalhan, S.C. In vivo differences between the turnover rates of leucine and leucine's ketoacid in stable cirrhosis. Gastroenterology 1992, 103, 571-578. [CrossRef]

39. Olde Damink, S.W.; Jalan, R.; Dejong, C.H. Interorgan ammonia trafficking in liver disease. Metab. Brain Dis. 2009, $24,169-181$. [CrossRef]

40. Shangraw, R.E.; Jahoor, F. Effect of liver disease and transplantation on urea synthesis in humans: Relationship to acid-base status. Am. J. Physiol. 1999, 276, G1145-G1152. [CrossRef]

41. Qiu, J.; Thapaliya, S.; Runkana, A.; Yang, Y.; Tsien, C.; Mohan, M.L.; Narayanan, A.; Eghtesad, B.; Mozdziak, P.E.; McDonald, C.; et al. Hyperammonemia in cirrhosis induces transcriptional regulation of myostatin by an NF-kappaB-mediated mechanism. Proc. Natl. Acad. Sci. USA 2013, 110, 18162-18167. [CrossRef]

42. Qiu, J.; Tsien, C.; Thapalaya, S.; Narayanan, A.; Weihl, C.C.; Ching, J.K.; Eghtesad, B.; Singh, K.; Fu, X.; Dubyak, G.; et al. Hyperammonemia-mediated autophagy in skeletal muscle contributes to sarcopenia of cirrhosis. Am. J. Physiol. Endocrinol. Metab. 2012, 303, E983-E993. [CrossRef]

43. Dasarathy, S. Myostatin and beyond in cirrhosis: All roads lead to sarcopenia. J. Cachexia Sarcopenia Muscle 2017, 8, 864-869. [CrossRef]

44. Tajiri, K.; Shimizu, Y. Branched-chain amino acids in liver diseases. Transl. Gastroenterol. Hepatol. 2018, 3, 47. [CrossRef]

45. Davuluri, G.; Allawy, A.; Thapaliya, S.; Rennison, J.H.; Singh, D.; Kumar, A.; Sandlers, Y.; Van Wagoner, D.R.; Flask, C.A.; Hoppel, C.; et al. Hyperammonaemia-induced skeletal muscle mitochondrial dysfunction results in cataplerosis and oxidative stress. J. Physiol. 2016, 594, 7341-7360. [CrossRef]

46. Nakaya, Y.; Harada, N.; Kakui, S.; Okada, K.; Takahashi, A.; Inoi, J.; Ito, S. Severe catabolic state after prolonged fasting in cirrhotic patients: Effect of oral branched-chain amino-acid-enriched nutrient mixture. J. Gastroenterol. 2002, 37, 531-536. [CrossRef] [PubMed]

47. Bugianesi, E.; Kalhan, S.; Burkett, E.; Marchesini, G.; McCullough, A. Quantification of gluconeogenesis in cirrhosis: Response to glucagon. Gastroenterology 1998, 115, 1530-1540. [CrossRef]

48. Owen, O.E.; Trapp, V.E.; Reichard, G.A., Jr.; Mozzoli, M.A.; Moctezuma, J.; Paul, P.; Skutches, C.L.; Boden, G. Nature and quantity of fuels consumed in patients with alcoholic cirrhosis. J. Clin. Investig. 1983, 72, 1821-1832. [CrossRef] [PubMed]

49. Anand, A.C. Nutrition and Muscle in Cirrhosis. J. Clin. Exp. Hepatol. 2017, 7, 340-357. [CrossRef]

50. Ye, J.; Palm, W.; Peng, M.; King, B.; Lindsten, T.; Li, M.O.; Koumenis, C.; Thompson, C.B. GCN2 sustains mTORC1 suppression upon amino acid deprivation by inducing Sestrin2. Genes Dev. 2015, 29, 2331-2336. [CrossRef]

51. Anda, S.; Zach, R.; Grallert, B. Activation of Gcn2 in response to different stresses. PLoS ONE 2017, 12, e0182143. [CrossRef]

52. Pakos-Zebrucka, K.; Koryga, I.; Mnich, K.; Ljujic, M.; Samali, A.; Gorman, A.M. The integrated stress response. EMBO Rep. 2016, 17, 1374-1395. [CrossRef]

53. Lu, P.D.; Harding, H.P.; Ron, D. Translation reinitiation at alternative open reading frames regulates gene expression in an integrated stress response. J. Cell Biol. 2004, 167, 27-33. [CrossRef] [PubMed]

54. Dasarathy, S.; Hatzoglou, M. Hyperammonemia and proteostasis in cirrhosis. Curr. Opin. Clin. Nutr. Metab. Care 2018, 21, 30-36. [CrossRef] [PubMed]

55. Tsien, C.; Davuluri, G.; Singh, D.; Allawy, A.; Ten Have, G.A.; Thapaliya, S.; Schulze, J.M.; Barnes, D.; McCullough, A.J.; Engelen, M.P.; et al. Metabolic and molecular responses to leucine-enriched branched chain amino acid supplementation in the skeletal muscle of alcoholic cirrhosis. Hepatology 2015, 61, 2018-2029. [CrossRef] [PubMed]

56. Davuluri, G.; Krokowski, D.; Guan, B.J.; Kumar, A.; Thapaliya, S.; Singh, D.; Hatzoglou, M.; Dasarathy, S. Metabolic adaptation of skeletal muscle to hyperammonemia drives the beneficial effects of l-leucine in cirrhosis. J. Hepatol. 2016, 65, 929-937. [CrossRef]

57. Ebadi, M.; Bhanji, R.A.; Mazurak, V.C.; Montano-Loza, A.J. Sarcopenia in cirrhosis: From pathogenesis to interventions. J. Gastroenterol. 2019, 54, 845-859. [CrossRef]

58. Grossmann, M.; Hoermann, R.; Gani, L.; Chan, I.; Cheung, A.; Gow, P.J.; Li, A.; Zajac, J.D.; Angus, P. Low testosterone levels as an independent predictor of mortality in men with chronic liver disease. Clin. Endocrinol. 2012, 77, 323-328. [CrossRef]

59. Monegal, A.; Navasa, M.; Guanabens, N.; Peris, P.; Pons, F.; Martinez de Osaba, M.J.; Ordi, J.; Rimola, A.; Rodes, J.; Munoz-Gomez, J. Bone disease after liver transplantation: A long-term prospective study of bone mass changes, hormonal status and histomorphometric characteristics. Osteoporos. Int. 2001, 12, 484-492. [CrossRef]

60. Moctezuma-Velazquez, C.; Low, G.; Mourtzakis, M.; Ma, M.; Burak, K.W.; Tandon, P.; Montano-Loza, A.J. Association between Low Testosterone Levels and Sarcopenia in Cirrhosis: A Cross-sectional Study. Ann. Hepatol. 2018, 17, 615-623. [CrossRef]

61. Sinclair, M.; Grossmann, M.; Hoermann, R.; Angus, P.W.; Gow, P.J. Testosterone therapy increases muscle mass in men with cirrhosis and low testosterone: A randomised controlled trial. J. Hepatol. 2016, 65, 906-913. [CrossRef] 
62. Kovacheva, E.L.; Hikim, A.P.; Shen, R.; Sinha, I.; Sinha-Hikim, I. Testosterone supplementation reverses sarcopenia in aging through regulation of myostatin, c-Jun NH2-terminal kinase, Notch, and Akt signaling pathways. Endocrinology 2010, 151, 628-638. [CrossRef]

63. Lonardo, A.; Carani, C.; Carulli, N.; Loria, P. 'Endocrine NAFLD' a hormonocentric perspective of nonalcoholic fatty liver disease pathogenesis. J. Hepatol. 2006, 44, 1196-1207. [CrossRef]

64. Anderson, L.J.; Tamayose, J.M.; Garcia, J.M. Use of growth hormone, IGF-I, and insulin for anabolic purpose: Pharmacological basis, methods of detection, and adverse effects. Mol. Cell. Endocrinol. 2018, 464, 65-74. [CrossRef] [PubMed]

65. Bodine, S.C.; Stitt, T.N.; Gonzalez, M.; Kline, W.O.; Stover, G.L.; Bauerlein, R.; Zlotchenko, E.; Scrimgeour, A.; Lawrence, J.C.; Glass, D.J.; et al. Akt/mTOR pathway is a crucial regulator of skeletal muscle hypertrophy and can prevent muscle atrophy in vivo. Nat. Cell Biol. 2001, 3, 1014-1019. [CrossRef] [PubMed]

66. Rommel, C.; Bodine, S.C.; Clarke, B.A.; Rossman, R.; Nunez, L.; Stitt, T.N.; Yancopoulos, G.D.; Glass, D.J. Mediation of IGF-1induced skeletal myotube hypertrophy by PI(3)K/Akt/mTOR and PI(3)K/Akt/GSK3 pathways. Nat. Cell Biol. 2001, 3, 1009-1013. [CrossRef] [PubMed]

67. Ceglia, L.; Harris, S.S. Vitamin D and its role in skeletal muscle. Calcif. Tissue Int. 2013, 92, 151-162. [CrossRef] [PubMed]

68. Sandri, M.; Sandri, C.; Gilbert, A.; Skurk, C.; Calabria, E.; Picard, A.; Walsh, K.; Schiaffino, S.; Lecker, S.H.; Goldberg, A.L. Foxo transcription factors induce the atrophy-related ubiquitin ligase atrogin-1 and cause skeletal muscle atrophy. Cell 2004, 117, 399-412. [CrossRef]

69. Gielen, E.; O’Neill, T.W.; Pye, S.R.; Adams, J.E.; Wu, F.C.; Laurent, M.R.; Claessens, F.; Ward, K.A.; Boonen, S.; Bouillon, R.; et al. Endocrine determinants of incident sarcopenia in middle-aged and elderly European men. J. Cachexia Sarcopenia Muscle 2015, 6, 242-252. [CrossRef]

70. Marcellin, P.; Kutala, B.K. Liver diseases: A major, neglected global public health problem requiring urgent actions and large-scale screening. Liver Int. 2018, 38 (Suppl. S1), 2-6. [CrossRef]

71. Chalasani, N.; Younossi, Z.; Lavine, J.E.; Charlton, M.; Cusi, K.; Rinella, M.; Harrison, S.A.; Brunt, E.M.; Sanyal, A.J. The diagnosis and management of nonalcoholic fatty liver disease: Practice guidance from the American Association for the Study of Liver Diseases. Hepatology 2018, 67, 328-357. [CrossRef]

72. Korinkova, L.; Prazienkova, V.; Cerna, L.; Karnosova, A.; Zelezna, B.; Kunes, J.; Maletinska, L. Pathophysiology of NAFLD and NASH in Experimental Models: The Role of Food Intake Regulating Peptides. Front. Endocrinol. 2020, 11, 597583. [CrossRef] [PubMed]

73. Neuman, M.G.; Cohen, L.B.; Nanau, R.M. Biomarkers in nonalcoholic fatty liver disease. Can. J. Gastroenterol. Hepatol. 2014, 28, 607-618. [CrossRef] [PubMed]

74. Schuppan, D.; Surabattula, R.; Wang, X.Y. Determinants of fibrosis progression and regression in NASH. J. Hepatol. 2018, 68, 238-250. [CrossRef]

75. Alisi, A.; Carpino, G.; Oliveira, F.L.; Panera, N.; Nobili, V.; Gaudio, E. The Role of Tissue Macrophage-Mediated Inflammation on NAFLD Pathogenesis and Its Clinical Implications. Mediat. Inflamm. 2017, 2017, 8162421. [CrossRef]

76. Trayhurn, P.; Wood, I.S. Adipokines: Inflammation and the pleiotropic role of white adipose tissue. Br. J. Nutr. 2004, 92, 347-355. [CrossRef]

77. Lang, C.H.; Frost, R.A.; Nairn, A.C.; MacLean, D.A.; Vary, T.C. TNF-alpha impairs heart and skeletal muscle protein synthesis by altering translation initiation. Am. J. Physiol. Endocrinol. Metab. 2002, 282, E336-E347. [CrossRef]

78. Reid, M.B.; Li, Y.P. Tumor necrosis factor-alpha and muscle wasting: A cellular perspective. Respir. Res. 2001, 2, 269-272. [CrossRef] [PubMed]

79. Zhou, J.; Liu, B.; Liang, C.; Li, Y.; Song, Y.H. Cytokine Signaling in Skeletal Muscle Wasting. Trends Endocrinol. Metab. 2016, 27, 335-347. [CrossRef]

80. Li, Y.P.; Chen, Y.; John, J.; Moylan, J.; Jin, B.; Mann, D.L.; Reid, M.B. TNF-alpha acts via p38 MAPK to stimulate expression of the ubiquitin ligase atrogin1/MAFbx in skeletal muscle. FASEB J. 2005, 19, 362-370. [CrossRef]

81. De Larichaudy, J.; Zufferli, A.; Serra, F.; Isidori, A.M.; Naro, F.; Dessalle, K.; Desgeorges, M.; Piraud, M.; Cheillan, D.; Vidal, H.; et al. TNF-alpha- and tumor-induced skeletal muscle atrophy involves sphingolipid metabolism. Skelet. Muscle 2012, 2, 2. [CrossRef]

82. Li, Y.P.; Schwartz, R.J.; Waddell, I.D.; Holloway, B.R.; Reid, M.B. Skeletal muscle myocytes undergo protein loss and reactive oxygen-mediated NF-kappaB activation in response to tumor necrosis factor alpha. FASEB J. 1998, 12, 871-880. [CrossRef] [PubMed]

83. Bhatnagar, S.; Panguluri, S.K.; Gupta, S.K.; Dahiya, S.; Lundy, R.F.; Kumar, A. Tumor necrosis factor-alpha regulates distinct molecular pathways and gene networks in cultured skeletal muscle cells. PLoS ONE 2010, 5, e13262. [CrossRef] [PubMed]

84. Morales, P.E.; Bucarey, J.L.; Espinosa, A. Muscle Lipid Metabolism: Role of Lipid Droplets and Perilipins. J. Diabetes Res. 2017, 2017, 1789395. [CrossRef] [PubMed]

85. Holland, W.L.; Brozinick, J.T.; Wang, L.P.; Hawkins, E.D.; Sargent, K.M.; Liu, Y.; Narra, K.; Hoehn, K.L.; Knotts, T.A.; Siesky, A.; et al. Inhibition of ceramide synthesis ameliorates glucocorticoid-, saturated-fat-, and obesity-induced insulin resistance. Cell Metab. 2007, 5, 167-179. [CrossRef]

86. Itani, S.I.; Ruderman, N.B.; Schmieder, F.; Boden, G. Lipid-induced insulin resistance in human muscle is associated with changes in diacylglycerol, protein kinase C, and IkappaB-alpha. Diabetes 2002, 51, 2005-2011. [CrossRef] [PubMed] 
87. Gladstone, J.N.; Bishop, J.Y.; Lo, I.K.; Flatow, E.L. Fatty infiltration and atrophy of the rotator cuff do not improve after rotator cuff repair and correlate with poor functional outcome. Am. J. Sports Med. 2007, 35, 719-728. [CrossRef]

88. Gerber, C.; Schneeberger, A.G.; Hoppeler, H.; Meyer, D.C. Correlation of atrophy and fatty infiltration on strength and integrity of rotator cuff repairs: A study in thirteen patients. J. Shoulder Elbow Surg. 2007, 16, 691-696. [CrossRef]

89. Kalinkovich, A.; Livshits, G. Sarcopenic obesity or obese sarcopenia: A cross talk between age-associated adipose tissue and skeletal muscle inflammation as a main mechanism of the pathogenesis. Ageing Res. Rev. 2017, 35, 200-221. [CrossRef]

90. Kohara, K.; Ochi, M.; Tabara, Y.; Nagai, T.; Igase, M.; Miki, T. Leptin in sarcopenic visceral obesity: Possible link between adipocytes and myocytes. PLoS ONE 2011, 6, e24633. [CrossRef]

91. Senn, J.J.; Klover, P.J.; Nowak, I.A.; Mooney, R.A. Interleukin-6 induces cellular insulin resistance in hepatocytes. Diabetes 2002, 51, 3391-3399. [CrossRef] [PubMed]

92. Boyraz, M.; Cekmez, F.; Karaoglu, A.; Cinaz, P.; Durak, M.; Bideci, A. Serum adiponectin, leptin, resistin and RBP4 levels in obese and metabolic syndrome children with nonalcoholic fatty liver disease. Biomark. Med. 2013, 7, 737-745. [CrossRef] [PubMed]

93. Boyraz, M.; Cekmez, F.; Karaoglu, A.; Cinaz, P.; Durak, M.; Bideci, A. Relationship of adipokines (adiponectin, resistin and RBP4) with metabolic syndrome components in pubertal obese children. Biomark. Med. 2013, 7, 423-428. [CrossRef] [PubMed]

94. Li, G.; Esangbedo, I.C.; Xu, L.; Fu, J.; Li, L.; Feng, D.; Han, L.; Xiao, X.; Li, M.; Mi, J.; et al. Childhood retinol-binding protein 4 (RBP4) levels predicting the 10-year risk of insulin resistance and metabolic syndrome: The BCAMS study. Cardiovasc. Diabetol. 2018, 17, 69. [CrossRef] [PubMed]

95. Oh, K.J.; Lee, D.S.; Kim, W.K.; Han, B.S.; Lee, S.C.; Bae, K.H. Metabolic Adaptation in Obesity and Type II Diabetes: Myokines, Adipokines and Hepatokines. Int. J. Mol. Sci. 2016, 18, 8. [CrossRef]

96. Diao, L.; Auger, C.; Konoeda, H.; Sadri, A.R.; Amini-Nik, S.; Jeschke, M.G. Hepatic steatosis associated with decreased betaoxidation and mitochondrial function contributes to cell damage in obese mice after thermal injury. Cell Death Dis. 2018, 9, 530. [CrossRef] [PubMed]

97. De Fre, C.H.; De Fre, M.A.; Kwanten, W.J.; Op de Beeck, B.J.; Van Gaal, L.F.; Francque, S.M. Sarcopenia in patients with non-alcoholic fatty liver disease: Is it a clinically significant entity? Obes. Rev. 2019, 20, 353-363. [CrossRef]

98. Sinha-Hikim, I.; Taylor, W.E.; Gonzalez-Cadavid, N.F.; Zheng, W.; Bhasin, S. Androgen receptor in human skeletal muscle and cultured muscle satellite cells: Up-regulation by androgen treatment. J. Clin. Endocrinol. Metab. 2004, 89, 5245-5255. [CrossRef]

99. Wu, Y.; Zhao, W.; Zhao, J.; Pan, J.; Wu, Q.; Zhang, Y.; Bauman, W.A.; Cardozo, C.P. Identification of androgen response elements in the insulin-like growth factor I upstream promoter. Endocrinology 2007, 148, 2984-2993. [CrossRef]

100. Liguori, I.; Russo, G.; Aran, L.; Bulli, G.; Curcio, F.; Della-Morte, D.; Gargiulo, G.; Testa, G.; Cacciatore, F.; Bonaduce, D.; et al Sarcopenia: Assessment of disease burden and strategies to improve outcomes. Clin. Interv. Aging 2018, 13, 913-927. [CrossRef]

101. Sinclair, M.; Grossmann, M.; Gow, P.J.; Angus, P.W. Testosterone in men with advanced liver disease: Abnormalities and implications. J. Gastroenterol. Hepatol. 2015, 30, 244-251. [CrossRef]

102. Donaghy, A.; Ross, R.; Wicks, C.; Hughes, S.C.; Holly, J.; Gimson, A.; Williams, R. Growth hormone therapy in patients with cirrhosis: A pilot study of efficacy and safety. Gastroenterology 1997, 113, 1617-1622. [CrossRef] [PubMed]

103. Bian, A.; Ma, Y.; Zhou, X.; Guo, Y.; Wang, W.; Zhang, Y.; Wang, X. Association between sarcopenia and levels of growth hormone and insulin-like growth factor-1 in the elderly. BMC Musculoskelet. Disord. 2020, 21, 214. [CrossRef]

104. Brioche, T.; Kireev, R.A.; Cuesta, S.; Gratas-Delamarche, A.; Tresguerres, J.A.; Gomez-Cabrera, M.C.; Vina, J. Growth hormone replacement therapy prevents sarcopenia by a dual mechanism: Improvement of protein balance and of antioxidant defenses. J. Gerontol. A Biol. Sci. Med. Sci. 2014, 69, 1186-1198. [CrossRef] [PubMed]

105. Wallace, J.D.; Abbott-Johnson, W.J.; Crawford, D.H.; Barnard, R.; Potter, J.M.; Cuneo, R.C. GH treatment in adults with chronic liver disease: A randomized, double-blind, placebo-controlled, cross-over study. J. Clin. Endocrinol. Metab. 2002, 87, 2751-2759. [CrossRef]

106. Han, H.Q.; Zhou, X.; Mitch, W.E.; Goldberg, A.L. Myostatin/activin pathway antagonism: Molecular basis and therapeutic potential. Int. J. Biochem. Cell Biol. 2013, 45, 2333-2347. [CrossRef] [PubMed]

107. Lee, S.J.; Lehar, A.; Meir, J.U.; Koch, C.; Morgan, A.; Warren, L.E.; Rydzik, R.; Youngstrom, D.W.; Chandok, H.; George, J.; et al. Targeting myostatin/activin A protects against skeletal muscle and bone loss during spaceflight. Proc. Natl. Acad. Sci. USA 2020, 117, 23942-23951. [CrossRef]

108. Becker, C.; Lord, S.R.; Studenski, S.A.; Warden, S.J.; Fielding, R.A.; Recknor, C.P.; Hochberg, M.C.; Ferrari, S.L.; Blain, H.; Binder, E.F.; et al. Myostatin antibody (LY2495655) in older weak fallers: A proof-of-concept, randomised, phase 2 trial. Lancet Diabetes Endocrinol. 2015, 3, 948-957. [CrossRef]

109. Woodhouse, L.; Gandhi, R.; Warden, S.J.; Poiraudeau, S.; Myers, S.L.; Benson, C.T.; Hu, L.; Ahmad, Q.I.; Linnemeier, P.; Gomez, E.V.; et al. A Phase 2 Randomized Study Investigating the Efficacy and Safety of Myostatin Antibody LY2495655 versus Placebo in Patients Undergoing Elective Total Hip Arthroplasty. J. Frailty Aging 2016, 5, 62-70. [CrossRef]

110. Saitoh, M.; Ishida, J.; Ebner, N.; Anker, S.D.; Springer, J.; von Haehling, S. Myostatin inhibitors as pharmacological treatment for muscle wasting and muscular dystrophy. J. Cachexia Sarcopenia Muscle Clin. Rep. 2017, 2, 1-10. [CrossRef]

111. Attie, K.M.; Borgstein, N.G.; Yang, Y.; Condon, C.H.; Wilson, D.M.; Pearsall, A.E.; Kumar, R.; Willins, D.A.; Seehra, J.S.; Sherman, M.L. A single ascending-dose study of muscle regulator ACE-031 in healthy volunteers. Muscle Nerve 2013, 47, 416-423. [CrossRef] 
112. Campbell, C.; McMillan, H.J.; Mah, J.K.; Tarnopolsky, M.; Selby, K.; McClure, T.; Wilson, D.M.; Sherman, M.L.; Escolar, D.; Attie, K.M. Myostatin inhibitor ACE-031 treatment of ambulatory boys with Duchenne muscular dystrophy: Results of a randomized, placebo-controlled clinical trial. Muscle Nerve 2017, 55, 458-464. [CrossRef] [PubMed]

113. Pearsall, R.S.; Davies, M.V.; Cannell, M.; Li, J.; Widrick, J.; Mulivor, A.W.; Wallner, S.; Troy, M.E.; Spaits, M.; Liharska, K.; et al. Follistatin-based ligand trap ACE-083 induces localized hypertrophy of skeletal muscle with functional improvement in models of neuromuscular disease. Sci. Rep. 2019, 9, 11392. [CrossRef] [PubMed]

114. Zhu, J.; Li, Y.; Lu, A.; Gharaibeh, B.; Ma, J.; Kobayashi, T.; Quintero, A.J.; Huard, J. Follistatin improves skeletal muscle healing after injury and disease through an interaction with muscle regeneration, angiogenesis, and fibrosis. Am. J. Pathol. 2011, 179, 915-930. [CrossRef] [PubMed]

115. Glasser, C.E.; Gartner, M.R.; Wilson, D.; Miller, B.; Sherman, M.L.; Attie, K.M. Locally acting ACE-083 increases muscle volume in healthy volunteers. Muscle Nerve 2018, 57, 921-926. [CrossRef] [PubMed]

116. Lach-Trifilieff, E.; Minetti, G.C.; Sheppard, K.; Ibebunjo, C.; Feige, J.N.; Hartmann, S.; Brachat, S.; Rivet, H.; Koelbing, C.; Morvan, F.; et al. An antibody blocking activin type II receptors induces strong skeletal muscle hypertrophy and protects from atrophy. Mol. Cell. Biol. 2014, 34, 606-618. [CrossRef]

117. Rooks, D.; Praestgaard, J.; Hariry, S.; Laurent, D.; Petricoul, O.; Perry, R.G.; Lach-Trifilieff, E.; Roubenoff, R. Treatment of Sarcopenia with Bimagrumab: Results from a Phase II, Randomized, Controlled, Proof-of-Concept Study. J. Am. Geriatr. Soc. 2017, 65, 1988-1995. [CrossRef]

118. Polkey, M.I.; Praestgaard, J.; Berwick, A.; Franssen, F.M.E.; Singh, D.; Steiner, M.C.; Casaburi, R.; Tillmann, H.C.; Lach-Trifilieff, E.; Roubenoff, R.; et al. Activin Type II Receptor Blockade for Treatment of Muscle Depletion in Chronic Obstructive Pulmonary Disease. A Randomized Trial. Am. J. Respir. Crit. Care Med. 2019, 199, 313-320. [CrossRef]

119. Hanna, M.G.; Badrising, U.A.; Benveniste, O.; Lloyd, T.E.; Needham, M.; Chinoy, H.; Aoki, M.; Machado, P.M.; Liang, C.; Reardon, K.A.; et al. Safety and efficacy of intravenous bimagrumab in inclusion body myositis (RESILIENT): A randomised, double-blind, placebo-controlled phase $2 \mathrm{~b}$ trial. Lancet Neurol. 2019, 18, 834-844. [CrossRef]

120. Rooks, D.; Swan, T.; Goswami, B.; Filosa, L.A.; Bunte, O.; Panchaud, N.; Coleman, L.A.; Miller, R.R.; Garcia Garayoa, E.; Praestgaard, J.; et al. Bimagrumab vs Optimized Standard of Care for Treatment of Sarcopenia in Community-Dwelling Older Adults: A Randomized Clinical Trial. JAMA Netw. Open 2020, 3, e2020836. [CrossRef] [PubMed]

121. Kumar, A.; Davuluri, G.; Silva, R.N.E.; Engelen, M.; Ten Have, G.A.M.; Prayson, R.; Deutz, N.E.P.; Dasarathy, S. Ammonia lowering reverses sarcopenia of cirrhosis by restoring skeletal muscle proteostasis. Hepatology 2017, 65, 2045-2058. [CrossRef]

122. Butterworth, R.F. L-Ornithine L-Aspartate for the Treatment of Sarcopenia in Chronic Liver Disease: The Taming of a Vicious Cycle. Can. J. Gastroenterol. Hepatol. 2019, 2019, 8182195. [CrossRef]

123. Hey, P.; Gow, P.; Testro, A.G.; Apostolov, R.; Chapman, B.; Sinclair, M. Nutraceuticals for the treatment of sarcopenia in chronic liver disease. Clin. Nutr. ESPEN 2021, 41, 13-22. [CrossRef] [PubMed]

124. Owen, O.E.; Reichle, F.A.; Mozzoli, M.A.; Kreulen, T.; Patel, M.S.; Elfenbein, I.B.; Golsorkhi, M.; Chang, K.H.; Rao, N.S.; Sue, H.S.; et al. Hepatic, gut, and renal substrate flux rates in patients with hepatic cirrhosis. J. Clin. Investig. 1981, 68, 240-252. [CrossRef]

125. Kabadi, U.M. The association of hepatic glycogen depletion with hyperammonemia in cirrhosis. Hepatology 1987, 7, 821-824. [CrossRef] [PubMed]

126. Cabre, E.; Abad-Lacruz, A.; Nunez, M.C.; Gonzalez-Huix, F.; Fernandez-Banares, F.; Gil, A.; Esteve-Comas, M.; Moreno, J.; Planas, R.; Guilera, M.; et al. The relationship of plasma polyunsaturated fatty acid deficiency with survival in advanced liver cirrhosis: Multivariate analysis. Am. J. Gastroenterol. 1993, 88, 718-722.

127. Enguita, M.; Razquin, N.; Pamplona, R.; Quiroga, J.; Prieto, J.; Fortes, P. The cirrhotic liver is depleted of docosahexaenoic acid (DHA), a key modulator of NF-kappaB and TGFbeta pathways in hepatic stellate cells. Cell Death Dis. 2019, 10, 14. [CrossRef]

128. Bischoff, S.C.; Bernal, W.; Dasarathy, S.; Merli, M.; Plank, L.D.; Schutz, T.; Plauth, M. ESPEN practical guideline: Clinical nutrition in liver disease. Clin. Nutr. 2020, 39, 3533-3562. [CrossRef]

129. Tsien, C.D.; McCullough, A.J.; Dasarathy, S. Late evening snack: Exploiting a period of anabolic opportunity in cirrhosis. J. Gastroenterol. Hepatol. 2012, 27, 430-441. [CrossRef]

130. Plank, L.D.; Gane, E.J.; Peng, S.; Muthu, C.; Mathur, S.; Gillanders, L.; McIlroy, K.; Donaghy, A.J.; McCall, J.L. Nocturnal nutritional supplementation improves total body protein status of patients with liver cirrhosis: A randomized 12-month trial. Hepatology 2008, 48, 557-566. [CrossRef] [PubMed]

131. Norman, K.; Kirchner, H.; Freudenreich, M.; Ockenga, J.; Lochs, H.; Pirlich, M. Three month intervention with protein and energy rich supplements improve muscle function and quality of life in malnourished patients with non-neoplastic gastrointestinal disease-A randomized controlled trial. Clin. Nutr. 2008, 27, 48-56. [CrossRef] [PubMed]

132. Manguso, F.; D'Ambra, G.; Menchise, A.; Sollazzo, R.; D'Agostino, L. Effects of an appropriate oral diet on the nutritional status of patients with HCV-related liver cirrhosis: A prospective study. Clin. Nutr. 2005, 24, 751-759. [CrossRef] [PubMed]

133. Les, I.; Doval, E.; Garcia-Martinez, R.; Planas, M.; Cardenas, G.; Gomez, P.; Flavia, M.; Jacas, C.; Minguez, B.; Vergara, M.; et al. Effects of branched-chain amino acids supplementation in patients with cirrhosis and a previous episode of hepatic encephalopathy: A randomized study. Am. J. Gastroenterol. 2011, 106, 1081-1088. [CrossRef] 
134. Marchesini, G.; Bianchi, G.; Merli, M.; Amodio, P.; Panella, C.; Loguercio, C.; Rossi Fanelli, F.; Abbiati, R.; Italian, B.S.G. Nutritional supplementation with branched-chain amino acids in advanced cirrhosis: A double-blind, randomized trial. Gastroenterology 2003, 124, 1792-1801. [CrossRef]

135. Muto, Y.; Sato, S.; Watanabe, A.; Moriwaki, H.; Suzuki, K.; Kato, A.; Kato, M.; Nakamura, T.; Higuchi, K.; Nishiguchi, S.; et al. Effects of oral branched-chain amino acid granules on event-free survival in patients with liver cirrhosis. Clin. Gastroenterol. Hepatol. 2005, 3, 705-713. [CrossRef]

136. Plauth, M.; Egberts, E.H.; Hamster, W.; Torok, M.; Muller, P.H.; Brand, O.; Furst, P.; Dolle, W. Long-term treatment of latent portosystemic encephalopathy with branched-chain amino acids. A double-blind placebo-controlled crossover study. J. Hepatol. 1993, 17, 308-314. [CrossRef]

137. Lo, J.H.T.; Pong, U.K.; Yiu, T.; Ong, M.T.Y.; Lee, W.Y.W. Sarcopenia: Current treatments and new regenerative therapeutic approaches. J. Orthop. Transl. 2020, 23, 38-52. [CrossRef]

138. Vahidinia, Z.; Azami Tameh, A.; Nejati, M.; Beyer, C.; Talaei, S.A.; Etehadi Moghadam, S.; Atlasi, M.A. The protective effect of bone marrow mesenchymal stem cells in a rat model of ischemic stroke via reducing the C-Jun N-terminal kinase expression. Pathol. Res. Pract. 2019, 215, 152519. [CrossRef]

139. Dabrowska, S.; Andrzejewska, A.; Lukomska, B.; Janowski, M. Neuroinflammation as a target for treatment of stroke using mesenchymal stem cells and extracellular vesicles. J. Neuroinflamm. 2019, 16, 178. [CrossRef] [PubMed]

140. Reza-Zaldivar, E.E.; Hernandez-Sapiens, M.A.; Gutierrez-Mercado, Y.K.; Sandoval-Avila, S.; Gomez-Pinedo, U.; Marquez-Aguirre, A.L.; Vazquez-Mendez, E.; Padilla-Camberos, E.; Canales-Aguirre, A.A. Mesenchymal stem cell-derived exosomes promote neurogenesis and cognitive function recovery in a mouse model of Alzheimer's disease. Neural Regen. Res. 2019, 14, 1626-1634. [CrossRef] [PubMed]

141. Cunningham, C.J.; Redondo-Castro, E.; Allan, S.M. The therapeutic potential of the mesenchymal stem cell secretome in ischaemic stroke. J. Cereb. Blood Flow Metab. 2018, 38, 1276-1292. [CrossRef] [PubMed]

142. Park, C.W.; Kim, K.S.; Bae, S.; Son, H.K.; Myung, P.K.; Hong, H.J.; Kim, H. Cytokine secretion profiling of human mesenchymal stem cells by antibody array. Int. J. Stem Cells 2009, 2, 59-68. [CrossRef] [PubMed]

143. Pourmohammadi-Bejarpasi, Z.; Roushandeh, A.M.; Saberi, A.; Rostami, M.K.; Toosi, S.M.R.; Jahanian-Najafabadi, A.; Tomita, K.; Kuwahara, Y.; Sato, T.; Roudkenar, M.H. Mesenchymal stem cells-derived mitochondria transplantation mitigates I/R-induced injury, abolishes I/R-induced apoptosis, and restores motor function in acute ischemia stroke rat model. Brain Res. Bull. 2020, 165, 70-80. [CrossRef] [PubMed] 